Rebecca Margolis

Oyfn Veg Session Two Discussion 
It is a great privilege to serve as respondent to these papers by Ira Robinson and Pierre Anctil at an event honouring Gerald Tulchinsky: each one of these senior scholars have served as mentors to me from my own beginnings as a young scholar in the field of Jewish Canadian Studies, and I owe them all a great debt of gratitude. As is evidenced in these two papers by Robinson and Anctil, the field of Canadian Jewish History has reached a place where it can take stock of where it stands. The discipline has evolved from an amateur pursuit to one comprised of professional historians who have brought it to scholarly conferences and into the university classroom. This is a most fitting tribute to Gerald Tulchinsky, one of the pioneering professional historians of Canadian Jewish life, who has not only built a prestigious career as an innovative, meticulous and generally excellent scholar but as a warm-hearted and generous individual who has inspired and encouraged countless scholars.

These two papers build on Tulchinsky's legacy as a historian of Jewish Canadian life. Robinson examines one of the most complex and difficult areas of Canadian Jewish historiography in his study of anti-Jewish sentiment in French Canada. As he states, 'The issue concerning the historical relationship between Jews and French Canadians is not merely fundamentally important for any responsible presentation of the historical development of Jews in Canada, it is also arguably the most controversial." Robinson does not shy away from potential controversy as he points to new areas of anti-Jewish sentiment in the forms of anti-Haredi and anti-Israel activity. Like so many historians of Jewish Canada before him, from B.G. Sack to Gerald Tulchinsky, Robinson draws on a wide array of sources in multiple languages and offers a nuanced narrative of Jewish Canadian history. Anctil points to the significance of Yiddish voices in the Jewish experience in Canada, a feature of that narrative that Tulchinsky has always highlighted by seamlessly incorporating a variety of sources into his writing, both in sidebars and in the main text, including Yiddish poetry.

\section{Reflections on Antisemitism in French Canada}

Robinsons's study of antisemitism, drawn from his forthcoming book on the subject, points to the persistent, cyclical nature of anti-Jewish sentiment in French Canada. His closing sentiment, a quote from from André Laurendeau-"Six million victims have not rooted out anti-Semitism. There are days when the progress of the human race seems dismally slow"-precludes the possibility of a linear interpretation that ends with an inevitable eradication of antisemitism. Rather, Robinsons highlights the different guises that anti-Jewish sentiment has taken in French Canada. In the eighteenth and nineteenth centuries, Jews were well integrated into British Canada and resented in French Canada as part of that group. While, as Robinson points out, they faced prejudice in political life, most famously in the case of Aaron Hart, the issues surrounding even this case were complex and enmeshed in wider struggles between a French Catholic majority and a British elite that dominated the economic and political realms. Simply put, "Jews and Judaism failed to become an overt po- 
litical issue in an ongoing way in early and mid-nineteenth century Canada." By the turn of the twentieth century, mass Jewish immigration and increased Jewish visibility changed the existing dynamic and brought new tensions. Rising resentments and anti-Jewish discourse expressed itself in the public sphere. The next and most well documented period, which coincides with the rise of Nazism, marked a period of increased hostility as well as powerlessness in the Jewish community. This era of anti-Jewish boycotts and small-scale violence marked the highpoint of overt anti-Jewish hostility. The post-War period marked a sea change and new efforts at rapprochement between Jews and French Canadians. However, it did not mark the end of antisemitism. Rather, anti-Jewish sentiment adopted new guises in the wake of Quebec nationalism came to fill the power vacuum left after the decline of the Catholic Church. The threat of Quebec sovereignty not only caused a mass exodus of Jews from the province in the 1970s, but it has also resulted in lasting uncertainties about the place of Jews within the province as new forms of anti-Jewish rhetoric emerged. Recent discussions of "religious accommodation" have formed a flashpoint for these tensions.

This element of his study points to the complexities of the subject and its ever-changing guise: as Robinsons puts it, "Plus ça change?" In the secularized state of the post-Quiet Revolution, Church leaders no longer preach anti-Jewish rhetoric from their pulpits. Jews are free to hold any political office and reside in any neighbourhood in the country. Canada no longer has immigration policies in place that single out Jews as undesirable. Canadian Jews are, on the whole, extremely well-integrated into Canadian society and no longer face institutionalized exclusion from the conduits of upward mobility - universities, access to many professional careersas did the mass Eastern European immigration of a century ago. As a group, Jews in Canada have been highly successful in maintaining their identities while also entering the mainstream.

Although I wish it were not so, I agree with Robinson that antisemitism in French Canada - and Canada as a whole-is far from dead. While many might have hoped that the atrocities of the Holocaust would offer a lesson in the potential dangers of anti-Jewish sentiment, its expressions have simply changed course. Much in the same way that modernity replaced longstanding beliefs that Jews were devils and poisoned wells with new notions about Jews as a racial group being harbingers of Capitalism (as well as Communism) who could not be loyal to the state, Robinson points to two new areas of anti-Jewish sentiment that have recently reared their heads. Like previous forms of antisemitism, these new forms are particularly nefarious because they are deemed socially acceptable in so many circles. The first targets the Haredi communities, who have been widely criticized in recent decades for their extreme rejection of modernity and secular life. As Robinson points out, this sentiment has been most vociferous in the Province of Quebec, home to a majority of the country's Haredi Jews and also a hotbed of political secularism. The second targets 
the modern State of Israel, where attacks on the country ranging from anti-Israel rhetoric to boycotts have become commonplace. Like other scholars in recent years, ${ }^{2}$ Robinson points to a shift in the parameters of antisemitism since the existence of the State of Israel to include expressions of anti-Israel sentiment.

Robinson's article indicates that antisemitism persists in Canada and will likely continue to evolve with time. Will it ever be gone? Probably not in our lifetimes.

\section{Yiddish Scholarship in Canada}

Anctil offers a dual argument on the state of Yiddish in Canada: he laments lack of knowledge among potential scholars to access Yiddish sources that are indispensable to understanding the Jewish experiencing in Canada while also celebrating the expansion of interest in Yiddish, notably in French Canada.

The first point is indisputable. Access to Yiddish sources opens up a wealth of documentation that is critical to gaining a nuanced understanding of Jewish life in Canada during and after the mass Eastern European immigration. And yet there are relatively few scholars who have accessed in depth this wealth of source material for research on Jewish life in Canada in its own right during the expansion of the field of Jewish Canadian history in the last three decades. The accounts of Jewish history authored by scholars with knowledge of Yiddish include the role of that language and culture as part of the narrative: in addition to Gerald Tulchinsky, the list includes: Irving Abella, Harold Troper, Ira Robinson, Richard Menkis, and Morton Weinfeld. For these scholars, accessing the Yiddish sources-newspapers and other primary documents, literary and religious texts-has formed a natural part of the research process in unearthing the history and contemporary life of Canadian Jewry. Rather than focus on the Yiddish experience per se, they have integrated it into their wider narratives, and there is much room for closer readings of immigrant adaptation in the Canadian context. And yet little has been written that examines the Yiddish experience in depth in its own right. Anctil suggests that this is due, at least in part, to a reticence during of a successfully integrated Canadian Jewish population to acknowledge a past where new Jewish immigrants sought to maintain a distinct language and culture in Yiddish: "As Canadian Jewish history races to reach a more palatable present, it tends to turn away from the study of earlier periods when Jews did not exemplify the Canadian norm - if such a concept ever existed.... By and large, when written in English, Canadian Jewish history has tended to gloss over the fact that there existed for at least half a century a period when Yiddish was dominant and when cultural production in that language was at its apex." As an author of numerous studies of Yiddish life in Canada myself, I am not convinced that the omission of the Yiddish component from the dominant narrative is not due to far more practical reasons, namely easy access to the language. The professionalization of Jewish Canadian History in last three few decades has coincided with a rapidly 
declining knowledge of Yiddish. Certainly, one can fault historians of Jewish Canada for not engaging in rigorous study of Yiddish in order to be able to delve into the treasure-trove of documents available in that language. However, this does not mean that these historians did not fully appreciate the Yiddish period of Jewish Canadian history; it simply was not their focus in their historical studies. For example, None is Too Many largely draws on Canada Canadian government archival materials - not written in Yiddish - to offer a narrative of the barring of European Jews from Canada between 1933-1948.

There is without doubt much to contribute to our understanding of the Yiddish experience in Canada, but the future of that narrative does not seem very sunny. Today there are few individuals, in particular under the age of sixty, who have reading knowledge of Yiddish strong enough to read texts of any kind. Even within Haredi circles, where Yiddish is a spoken language, members are not trained to read literary and scholarly texts in the language. Rather, loshn-koydesh (Hebrew-Aramaic) is the accepted mark of literacy while reading secular texts in Yiddish such as poetry would be anathema to their traditionally religiously observant world. Further, Yiddish is no longer being taught in secular Jewish elementary and high schools at a level that creates readers of the language, and, with just a tiny number of households outside of the Haredi communities speaking the language, few individuals are exposed to the language in other ways. Universities rarely offer classes beyond the beginner level and there is no Yiddish country to visit to have an immersion experience. Even intensive Yiddish programs, which excel in their effectiveness at teaching the language, rarely offer continuity that allows students to reach true fluency.

I am less convinced of Anctil's second point. Anctil posits the following rationale for the interest of Quebecers in Yiddish: "Here was another minority striving to create for itself an institutional structure propitious to the preservation of a unique language and culture." Anctil posits the "Main" as a locus of diversity and "meeting of cultures" between French Quebecers and Jews: in Jewish stores, garment factories or outdoors in parks, or among artists. It would be fascinating to explore accounts of these passive points of encounter and the impact they might have had on an emerging Quebecois identity decades before the Quiet Revolution. Certainly, in terms of infrastructure, there are parallels between the experience of French Canadians and Yiddish-speaking Jews of the first half of the twentieth century in their ventures to preserve and promote a language-centered culture. Both groups, for example, heavily employed secular education to meet their goals. However, the historical contexts are so radically divergent that the parallel becomes almost anachronistic. French Quebecers successfully elevated the status of their language to the dominant vernacular in a newly secularized society after centuries of suppression, and they did so with full political and financial support of a state with strong separatist leanings. In contrast, Canada's Jews as a group voluntarily acculturated into the English milieu within a generation of their arrival in Canada while simultaneously 
maintaining strong ties to their Yiddish culture. Anctil presents Yiddish speakers as an idealized case of language maintenance and social conscience when, in fact, they all too soon adopted the dominant language of Canadian life and achieved upward mobility, a trend he criticizes historians for highlighting: "a closer examination of Yiddish history will probably provide us with new insights on how the country was progressively exposed to new notions of artistic creativity, social justice and working class solidarity, in forms that Canadians could not quite bring to fruition from their own internal perspective." There was never a question, even among its most ardent activists, that Yiddish would serve as lingua franca longterm for Canadian Jewry; Yiddish Jews with any separatist aspirations looked to faraway Birobidzhan. The extent of this voluntary linguistic assimilation, which represented the ticket to successful integration into Canada, is evidenced by the fact that all of these Yiddish activists' children became English speakers, even those who remained fluent Yiddish speakers and have made great contributions to the promotion of Yiddish: Irving Massey (son of Ida Maza), Goldie Morgentaler (daughter of Chava Rosenfarb), David Roskies (scholar of Yiddish), to name just a few.

Despite the significance of Yiddish documentation to understanding the Jewish Canadian experience and the importance of translation to rendering them accessible to a wider public, there has not been much traction in this area. It is no coincidence that all of the French-language translations mentioned in the article are by Anctil himself, or by Chantal Ringuet, who studied with Anctil as a postdoctoral student at the University of Ottawa. Anctil, who has devoted himself tirelessly to the study of Yiddish and consulting with native speakers as needed to unearth, translate and annotate a vast corpus of Yiddish prose, essays and memoirs, has opened up access to sources on the Montreal Jewish immigrant experience that would otherwise remain completely unknown. As a Canadian scholar and teacher of Yiddish Studies myself, I certainly wish this dedication to exploring and rendering Yiddish works in translation was a wider trend among scholars and translators in Canada but there is, at present, no evidence of this. Anctil's French renditions of the memoirs of Israel Medres did inspire Vivian Felsen, Medres's own granddaughter, to translate her grandfather's writings into English. However, his vast body of Yiddish translations into French have not given birth to a school of translators or scholars of Yiddish Canada within French circles. The situation is not much better in English circles, where one likewise cannot point to the emergence of a new group of scholars or translators. The English works cited by Anctil are largely the products of individuals who stem from the milieu when Yiddish was a widely spoken language among the immigrant generation, and who translate for the sheer pleasure of it. These pursuits are not attracting younger scholars or translators. Why might this be the case?

The answer has to do with resources. The study or translation of Yiddish is not backed by any infrastructure in Canada. While there is support available to Yiddish translators from American organization, notably the Yiddish Books Center in Amherst, 
MA, Yiddish translation in Canada has no institutional home. Rather, pursuits in Yiddish translation into both official languages are fractured, with individuals largely working in isolation. There is no shared forum, and, perhaps most importantly, no institutional support. In short, as Anctil's essay indicates, Yiddish remains a labour of love. Without an easily accessible milieu in which to learn and use Yiddish, accessing Yiddish beyond the walls of a classroom is difficult, and oftentimes lonely indeed.

\section{Concluding remarks}

Perhaps the greatest contribution of these studies by Robinson and Anctil's is the ways in which they offer new possibilities for discussion. I have every intention of assigning them to my students in Jewish Canadian Studies to provide a glimpse into the state of the field. This fruitful exchange marks part of the great legacy of Gerald Tulchinsky.

1

See, for example, Richard Menkis's analysis, which suggests that the opposition to Hart's taking office was an expression of anti-British sentiment. Richard Menkis, "Antisemitism in the Evolving Nation: From New France to 1950." In From Immigration To Integration, The Canadian Jewish Experience: A Millennium Edition. (Ed) Frank Dimant and Ruth Klein (Toronto: B'nai Brith Canada, Institute for International Affairs, 2001), 31-51.

\section{2}

For example, Jonathan Judaken, “So What's New? Rethinking the 'New Antisemitism' in a Global Age," Patterns of Prejudice, $42: 4$ (2008): 531-560. 